\title{
Közösségi tervezés 2.0: a participáció új perspektívái a webkettó fényében
}

\section{Community Planning 2.0: new perspectives in participative planning in the light of Web 2.0}

\author{
RÉNYI ZSOLT
}

KULCSSZAVAK: web 2.0, participatív tervezés, térinformatika, területi tervezés, közösségi tervezés

ABSZTRAKT: A tanulmány azł vizsgálja, hogy az új, közösségi részvételre építő webalapú alkalmazások segítségével hogyan tehető teljesebbé és hatékonyabbá a területi tervezés. Elsősorban arra keresi a választ, hogyan illeszkedik egymásba a közösségi tervezés és a közösségi web jelenségének "filozófiája”, illetve miként válhat a participáció hasznára a web 2.0 jelensége. Megállapítható, hogy a webkettő eszközei a térhasználatra is hatással vannak, valamint, hogy új perspektívát nyújtanak a közösségi tervezés számára.

KEYWORDS: participative planning, collaboration, web 2.0, community planning, GIS

ABSTRACT: Participative (or participatory) planning, $i$. e. the involvement of stakeholders and the general public in the creation of their future, is an ever more frequently used method in community planning. It requires and fosters communication, the integration of knowledge and insights at grassroots level and the democratisation of the processes of formulating strategies and visions. Participative planning uses similar platforms as social networks do (Web 2.0) which have become a new paradigm in internet communications and content provision during the past decade. Web 2.0 is a content providing and information sharing concept. Where second-generation web and collaborative planning arecombined, one finds new web-based applications (Geographic Information Systems GIS) which greatly enhance existing methods of community participation and knowledge sharing.

This study focuses on describing the parallels between the bottom-up and decentralised perspectives of participative planning and Web 2.0. Both phenomena thrive on communities' members taking a proactive role in creating what they eventually "consume". In the case of participative community planning, it is their environment. In Web 2.0, it's usually content - such as an enyclopedia or a community content sharing platform. Participative planning project leaders are increasingly making use of Web 2.0 technologies to facilitate peer collaboration among stakeholders and the public. An almost purely Web 2.0-based community planning project (PPGIS; Peng 2001) is used as an example.

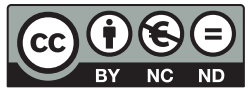




\section{Bevezetés}

A gondolat, amely szerint érdemes bevonni az állampolgárokat az őket érintő tervek elkészítésébe, már 1969-ben Arnsteinnél megjelenik; a hetvenes évek eleje óta pedig mind markánsabb szerepet kap e koncepció, a participatív tervezés. A kilencvenes évek végére az infokommunikációs eszköztár bővülése tágítja a részvételen alapuló tervezés lehetőségeit azáltal, hogy új eszközöket kapott az úgynevezett web 2.0-s oldalak és informatikai alkalmazások megjelenésével. Egyre több webes alkalmazás teszi lehetővé, hogy a kollaboratív munka optimális hatásfokkal történjen térben egymástól távol eső résztvevők között. Ezen web 2.0-ásnak elnevezett (O’Reilly 2005) online szoftverek a legkülönbözőbb iparágakban és szakterületeken jelentek meg; a területi tervezésben pedig elsősorban a participatív tervezésben hoznak újat.

Fontos megemlíteni, hogy mind a webkettőnek, mind a közösségi részvételnek jelentős vetülete van a demokráciára és a kormányzásra, államigazgatásra nézve. Ezt a területet - a web 2.0 megnevezés mentén - democracy 2.0-nak, illetve government 2.0-nak is nevezik, és külön szakterületet képeznek. Ezek azonban - bár rokonterületek - kívül esnek e cikk spektrumán. A cikk célja, hogy röviden ismertesse a web 2.0 jelenséget, majd rámutasson azokra az új lehetőségekre, amelyek kiegészítik és hatékonyabbá teszik a részvételi tervezés folyamatát.

\section{A web 2.0 és a participáció}

A webkettő - más néven a „közösségi web” összetett jelenség, amelynek definiálására és körbehatárolására több ezer cikk, blogbejegyzés és az ezekre érkező megannyi hozzászólás vállalkozik. Mivel a jelenség sokrétű, hiszen - többek között - tartalomszolgáltatási, technológiai, üzletfilozófiai és szociológiai vetülete van, nincs egy átfogó és általánosan elfogadott definíció a web 2.0-ra. O'Reilly (2005) használta először a fogalmat egy általa szervezett konferencia neveként. O'Reilly nyomán indult el a web 2.0 forradalom az ITszektorban, amelyben „elmozdulás történik az internet mint platform irányába és kísérlet az üzleti siker törvényszerüségeinek feltárására ezen a platformon. A törvényszerüségek között az elsö: épits olyan alkalmazásokat, melyek megragadják a hálózati hatást, és az által válnak jobbá, hogy minél többen használják. (Erre korábban úgy utaltam, mint a „kollektív intelligencia megragadására)" (O’Reilly 2006.).

A definíció legfontosabb eleme: olyan internetes alkalmazás vagy weboldal, aminek annál nagyobb az értéke, minél több aktív használója/felhasználója van. A web 2.0 fogalma, definíciója felől még ma sem teljes az egyetértés; 2004-es megjelenését követően még a fogalom létezésének szükségességét is megkérdőjelezik egyebek közt azért, mert a kifejezést O’Reilly egy konferen- 
cia címeként alkotta (Graham 2005). A Wikipedia - a közösségi web és a kollaboráció iskolapéldája - O’Reilly-nél általánosabban, felhasználói oldalról fogalmazza meg azt a jelenséget, amelynek nyomán maga a webes enciklopédia létrejött. A Wikipedián található web 2.0 definíció: „...olyan második generációs internetes szolgáltatások gyüjtőneve, amelyek elsősorban a közösségre épülnek, azaz a felhasználók közösen készitik a tartalmat, vagy megosztják egymás információit. Ellentétben a korábbi, első és másfeledik generációs szolgáltatásokkal, amelyeknél a tartalmat, a szolgáltatást nyújtó fél biztositotta (például a portáloknál), webkettes szolgáltatásoknál a szerver gazdája csak a keretrendszert biztosítja, a tartalmat maguk a felhasználók töltik fel, hozzák létre, megosztják vagy véleményezik. A felhasználók jellemzően kommunikálnak egymással, és kapcsolatokat alakítanak ki egymás között" (en.wikipedia.org).

A közösségi web paradigmaváltást jelent a tartalomszolgáltatásban is; az interneten megjelenő tartalom szolgáltatójának és befogadójának hagyományos szerepe felbomlik, mely szerepkör-módosulás, mint azt később bemutatom, jelentős változást hoz a területfejlesztés lehetőségeiben. E szerepmódosulásnak a lényege: a web 1.0 korában kevesen adtak tartalmat sokaknak, viszonylag szűk réteg privilégiuma volt a tartalommegosztás. E modellben a tartalom hub-and-spoke-szerüen ${ }^{1}$ áramlik egy vagy több központból a perifériák felé úgy, hogy a perifériáknak kevés vagy semennyi kezdeményezési és egymással interakcióba lépési lehetősége sincsen. Ezzel szemben, a web 2.0 keretében már nagyon sokan adnak sok ember számára tartalmat; (many-to-many kommunikáció). Azaz, a közösségi internet korában minimalizálódnak az információs privilégiumok; sok kis egyszemélyes újság is létezhet (ezek pl. a blogok). A webkettő korában „a felhasználó gyártja is a tartalmat, vagy a közösségi hálózatokban a felhasználó maga a tartalom" (Berényi 2008).

Alapvető tézis e cikkben, hogy a közösségi web (meghatározásából következően), valamint az részvételen alapuló tervezés (kollektív és kollaboratív jellege révén) hasonló alapokon állnak. A webketto „filozófiája” és gyakorlata nem más, mint a tartalom/tudás előállításának és terjesztésének a decentralizációja rendszerint alulról szerveződő, kollaboratív módon. Mind a webkettes-filozófia, mind a részvételen alapuló, közösségi tervezés feszegeti azt a hagyományos gondolkodási keretet, amely szerint egy adott problémakörhöz kapcsolható embereket „szakértő" és „laikusok” csoportjára lehetne osztani. E meghatározások a közgondolkodásban gyakorlatilag a „hozzáértő” és „amatőr" kifejezéseket takarják (Pataki 2007). Ezért, álláspontom szerint, ennek a módszernek helye van a területi tervezésben is. Jeffrey (2003) felhívja a figyelmet: a társadalomtudományok számára is alapvető kihívás, hogy integrálják azokat a vélhetően és nyilvánvalóan hasznos tapasztalatokat és tudást, amelyek tudományos mérce szerint nem teljesek, vagy nehezen kifejezhetők objektív módon. Ennek a feladatnak a hatékonyabb ellátását segítik a tervezés során bevont webkettes eszközök, ahogy azt a későbbiekben látni fogjuk. Jeffrey rámutat egy nagyobb léptékü összefüggésre is, mely szerint: „E [laikusok- 
ról és szakértőkről szóló] vita messze túlmutat a tervezés, participáció és a részvétel kérdéskörén. Ezek a témák a tudomány és a társadalom, az absztrakt és a tapasztalható, a logika és érzelem [...] közti kapcsolat lényegét feszegetik" (Jeffrey 2003, 3.).

Sain (2008) áttekintést nyújt arról, hogy miben különböznek a terv kiérlelésének egyes mozzanatai külső-konzultatív, illetve egy belső tervező munkája során. (A belső tervező a közösségi tervezés során alkalmazott facilitátor ${ }^{2}$.) Az 1. táblázat összegzi a külső és a belső tervezés közti különbségeket.

1. táblázat: Külső kontra belső tervezés

\begin{tabular}{ll}
\hline \multicolumn{1}{c}{ Külső tervezés } & \multicolumn{1}{c}{ Belső tervezés } \\
\hline $\begin{array}{l}\text { Az összegyüjtött információ a tervező } \\
\text { kezében van }\end{array}$ & $\begin{array}{l}\text { Az összegyüjtött információ a közösség } \\
\text { kezében marad }\end{array}$ \\
$\begin{array}{l}\text { A terv a tervező fejében jön létre } \\
\text { Az érintettek egymástól elszigetelten }\end{array}$ & A terv az érintettek fejében jön létre \\
kerülnek kapcsolatba a tervvel & Az érintettek kapcsolatba kerülnek \\
\hline
\end{tabular}

Forrás: Sain (2008).

E három különbség szinte szó szerint lefordítható néhány web 1.0 és web 2.0 közti különbség ábrázolására a 2. táblázat szerint.

2. táblázat: Web 1.0 kontra web 2.0

\begin{tabular}{ll}
\hline \multicolumn{1}{c}{ Web 1.0 } & \multicolumn{1}{c}{ Web 2.0 } \\
\hline Az összegyüjtött információ a & Az Összegyújtött információ a közösség \\
tartalomszolgáltató kezében van & kezében marad \\
$\begin{array}{l}\text { A website tartalma/projekt a tervező } \\
\text { fejében jön létre }\end{array}$ & $\begin{array}{l}\text { A website tartalma/projekt a közösség } \\
\text { "fejében” jön létre }\end{array}$ \\
$\begin{array}{l}\text { Az érintettek egymástól elszigetelten } \\
\text { kerülnek kapcsolatba a }\end{array}$ & $\begin{array}{l}\text { Az érintettek kapcsolatba kerülnek } \\
\text { tartalommal/projekttel }\end{array}$ \\
\hline
\end{tabular}

Forrás: saját szerkesztés.

A fentihez hasonló szempontokat, ám jóval részletesebb táblázatot ismertet a web 2.0 fogalom keresztapja, O’Reilly (2005) is. A területi tervezés, illetve a web régi és új iskolái közti különbségekben a közös nevező: a döntések, feladatok, felelősség és általánosságban az ezekhez kapcsolódó feladatok decentralizációja; a bölcs vs. laikus szerepfelfogásnak, differenciálásnak a háttérbe szorulása. E nagyon lényeges és alapvető közös vezérelv teszi lehetővé, hogy a web 2.0 eszközeit sikerrel alkalmazzák a részvételi közösségi tervezésben. 


\section{Webkettó: térbeliség és a közösségi tervezés}

A webkettő és a participáció ismertetése után azt vizsgálom, hogy e technológia vonatkozásai hogyan jelennek meg a térbeliség témakörében, illetve hogyan integrálhatók a közösségi tervezésbe. Konkrétabban: hogyan befolyásolja ez az új technológia, illetve szemlélet az egyén és a tágabb közösségek térhasználatát $s$ végül a területi tervezés menetét?

Elöljáróban szólni kell arról az általános tendenciáról, amely szerint a technológiai lehetőségek kibővülésével egyre nagyobb az igény az időszerű és helyspecifikus információra, így a helyben levőség és a „valós-idejűség” egyszerre teljesülhet - elsősorban a tartalom- és információszolgáltatásban. Ugyanakkor a tartalom felhasználója/befogadója számára irrelevánssá válik földrajzi helyzete: a megfelelő eszközök és platformok segítségével bárhol, bármikor hozzáférhetővé válik az idő- és helyszínszenzitív tartalom. Ilyenek például a wiki-jellegü útikönyvek, amelyek tartalmát maguk a felhasználók hozzák létre és frissítik. Az ilyen wiki-szerü útikönyvek lehetővé teszik, hogy GPS-koordinátákkal ellátott, Google Earth-alkalmazásra feltöltött fényképek és megváltozott nyitva tartási információk azonnal felkerüljenek a világhálóra. Ezzel szemben a hagyományos útikönyvkiadók legjobb esetben négyévente adnak ki új köteteket, így nem tudnak lépést tartani a "wiki-jelenség” mentén születő „aktualitási versenyben” (www.wikitravel.org 2009). Mivel egyre inkább elvárás, hogy az ilyen jellegü, például utazással kapcsolatos információk hiperfrissek legyenek, ezért felértékelődik a tartalom létrehozójának földrajzi helyzete. A tartalom befogadójának földrajzi helyzete pedig egyre inkább irrelevánssá válik, mert bármilyen internetkapcsolattal rendelkező - akár mobil - eszközön keresztül hozzáfér a legfrissebb információhoz. Ebben a példában sok tízezer, egymás számára jobbára ismeretlen ember személyes, helyi tudása válik mindenki számára elérhető explicit tudássá. Figyelemre méltó továbbá, hogy egy globális, új eszköz/technológia segítségével a helyi tudás, helyi kompetenciák felértékelődnek; pontosabban „piacképessé”, azaz „eladhatóvá” válnak. A technológia rendelkezésre állása előtt ugyanilyen fontos volt a helyspecifikus, naprakész információ, de az egyáltalán nem, vagy alig volt hozzáférhető. A (mobil eszközökön is elérhető) világháló mint infrastruktúra, valamint a tartalomszolgáltatásban végbemenő decentralizációs tendencia (értsd: webkettes alkalmazások megjelenése) teszi lehetővé a helyi tudás megosztását és elérhetőségét. Erre a jelenségre példaként szolgál a későbbiekben bemutatandó esettanulmány.

Fontos megjegyezni, hogy új infokommunikációs technológián alapuló megoldások a területfejlesztésben is megjelentek bő másfél évtizeddel ezelőtt, de ezek a tartalomszolgáltatás terén rendszerint hierarchikusan épülnek fel, a „web 1.0-ás filozófia" szellemében; az információ hub-and-spoke modell sze- 
rint áramlik egy vagy több központból a perifériák felé úgy, hogy a perifériáknak kevés vagy semennyi kezdeményezési és egymással interakcióba lépési lehetősége nincsen. Jó példa az ilyen top-down architektúrára egy ugandai és ghánai farmerek részére a helyi földművelésügyi minisztériumok által létrehozott rendszer, amelyben a csekély agrártudással dolgozó farmerek rendszeresen SMS-üzenetekben kapnak tanácsokat birtokuk és földjük műveléséhez (Karamagi, Nakirya 2007). Az ilyen architektúrák nem feltétlen rosszabbak a hálózati jelleggel bíró, részvételre épülo”, „,webkettes filozófia” szerint működő, interaktív rendszereknél. A webkettes alapon működő rendszerek azonban egy újabb lépcsőfokot jelentenek tartalomszolgáltatási és tudásmegosztási szempontból, hiszen lehetővé teszik a résztvevők közti információáramlást, ezáltal továbbörökítve a résztvevők - rendszerint - pragmatikusabb, tapasztalatokon alapuló tudását is. A második generációs, alulról építkező struktúrák a fenti példával ellentétben többnyire a térhasználatot is módosítják, mint ahogy a Wikitravel esetén bemutattam.

\section{Modell a webkettó alapú közösségi tervezésre}

A webkettő alapú participatív tervezési gyakorlat bemutatása előtt érdemes áttekinteni, hogy hogyan jelent meg a közösségi részvétel a területi tervezésben. Az előző évszázad során a tervezés elsősorban a tudományos megközelítéstől és a technika alkalmazásától remélte annak megfejtését, hogy hogyan legcélszerűbb megtervezni, irányítani a településeket és a regionális tereket (Friedmann 1987 in Gunder 2003).

Számos kutatási eredmény (Sager 2009) alátámasztja, hogy egyebek közt a demokratikus jogok gyakorlása iránti igény eredményezi a közvetlen közösségi részvétel felértékelődését, elterjedését. Sarkissian (2002) megjegyzi, hogy ez a jelenség túlmutat egyfajta fogyasztói forradalmon - amely elmélet szerint a polgárok/fogyasztók öntudatukra ébredésének egyik jele lenne az, hogy több beleszólást akarnak az ő életüket meghatározó döntések meghozatalába. Ehelyett nagyobb léptékủ fejleménynek tulajdonítja e jelenséget, mégpedig azt, hogy az állampolgárok számonkérik demokratikus jogaikat, követelik lehetőségeik bővítését. Ezzel szemben álláspontom az, hogy mind a webkettő jelensége, mind a részvételi demokrácia növekvő népszerüsége (a képviseleti demokráciába vetett hitnek a kárára) egy nagy ívű decentralizációs és demokratizáló folyamatnak egymással összefüggő jelenségei. E jelenségek közé sorolható a fogyasztók bevonása/bevonódása a termékfejlesztésbe, továbbá az önkéntesség és számtalan egyéb „proaktív” megnyilvánulás az állampolgárok részéről. Ezeket a fogyasztókat/állampolgárokat - lévén, hogy egyszerre fogyasztók és termelők, angolul producerek és consumerek - Toffler (2006) prosumereknek keresztelte el, és prosumer-forradalomnak hívja az imént 
taglalt sokrétű tendenciát. A demokratikus jogok gyakorlásának számonkérése vélhetően tehát nem értékesebb/több, és nem kevesebb, mint a fogyasztói forradalmak, hanem több tényező/trend különböző megnyilvánulásai, amelyek közös pontja az, hogy az emberek mindinkább saját kezükbe akarják venni az életüket irányító tényezők és körülmények fölötti uralmat. Sarkissian alapján $(2002,2$.) íme néhány trend a közösségi-lakossági szférából, amelyek a participációra ösztönzőleg hatnak:

- Nő a közösségek igénye a közvetlen beleszólásra a közös ügyeiket érintően.

- Felgyorsulnak a társadalmi változások, a társadalom egyre sokszínűbbé válik, s ezzel a közigazgatásnak nehéz lépést tartania.

- Bizalomvesztés zajlik a politika és a szakértők iránt.

- Csökken az információs aszimmetria a nem helyi hivatalnokok és a helyi lakosok közt - az új és jobb minőségű információs forrásoknak köszönhetően a "laikus" állampolgár nagyobb tudásra tehet szert bizonyos témákban, mint egy vezető.

- Alapvető igény jelentkezik a proaktivitás iránt, amit a korszellem is propagál.

- Növekvő iskolázottsági szint mellett növekszik a munkanélküliség, és emelkedik a képzett nyugdíjasok száma.

A közösségi tervezés módszertanát, gyakorlatát számos kézikönyv, kutatás és esetfeldolgozás taglalja. A kiemelkedő művek közé tartozik Wates (1996) Action Planning, valamint Kaner et al. (1996) The facilitator's guide to participatory decision-making című műve. Mielőtt szemügyre vennénk példákat webalapú participációs tervezésre, érdemes röviden ismertetni azt a módszertant, folyamatot, amit „webre viszünk”. Az alábbiakban tehát röviden bemutatom a közösségi tervezés típusai - hagyományos, „offline” felállásban.

A közösségre kiható tervezést az érintettek bevonásának mértéke szempontjából hat kategóriába soroljuk. Ezeket Sain (2008, 9-14.) Arnstein (1969) nyolclépcsős modellje alapján a következőkben határozza meg:

1. Passzív részvétel: a tervezők nem vonják be az érintetteket, csupán tájékoztatják őket.

2. Részvétel információszolgáltatáson keresztül: ebben az esetben az érintettek szerepe a tervezők által feltett kérdések megválaszolása a közösség itt gyakorlatilag kérdöíveken, fórumokon adja át tapasztalatát, a tervezésben nem vesz részt.

3. Részvétel konzultáción keresztül: a döntéshozatalba továbbra se vonják be az érintetteket, de konzultatív módon a tervező által meghatározott megoldásokat vitathatják, finomíthatják.

4. Funkcionális részvétel (delegáció): a tervezők által előre megállapított célokkal és feladatokkal foglalkozó munkacsoportokat, bizottságokat hoznak létre az érintettek. Erre a tervezés későbbi szakaszában 
kerülhet sor. Ezt a stádiumot rendszerint információszolgáltatás vagy konzultáció előzi meg.

5. Interaktív részvétel (partnerség): az érintettek közös elemzéseken vesznek részt, amelyek eredményeként akciótervek születnek. Új helyi intézmények alakulnak. A folyamat interdiszciplináris, és egyfajta strukturált tanulási folyamatot eredményez. Ebben a fázisban a csoportoknak már van beleszólásuk a helyi döntésekbe.

6. Önálló kezdeményezés (facilitálás): a résztvevők külső tervezőktől/intézményektől függetlenül, önállóan állnak elő javaslatokkal egy probléma megoldására. A szakértő (facilitátor) belülről érkezik, vagy külső intézményektől. A döntési jogkör, beleértve a források felhasználását, a résztvevők körében marad.

Jellegénél fogva a közösségi tervezés lehetővé teszi, hogy egy adott projekten belül a fentiek közül több fázis megvalósuljon. Így például a tágabb közösség tájékoztatása és igényeinek felmérése (1. passzív részvétel és 2 . részvétel információszolgáltatáson keresztül) alapvető fontosságú azon projektek esetében is, ahol később interaktív partnerség kialakulására (5. szint) kerül sor. Felmerül a kérdés, hogy mik az előnyei, illetve hátrányai/buktatói annak, hogy webalapra kerül át a participatív tervezés. A legfontosabb lehetőségek:

- Széles társadalmi részvételre való lehetőség. A webkettes rendszerek lehetővé teszik, hogy az adott tervezési fázis szakaszán belül a résztvevő bármely időpontban hozzájáruljon a tervhez akármilyen internetkapcsolattal rendelkező számítógépről (szemben a valódi fókuszcsoportos eseményekkel, amelyeket fix helyszínen és időpontban rendeznek meg). Másrészről sok ember kényelmetlennek érzi véleményét kifejezni lakossági gyűléseken és fókuszcsoportokban; ők nagyobb hajlandósággal vesznek részt online közegben, ahol anonim módon, írásban járulhatnak hozzá a vitához (Peng 2001). Megjegyzendő, hogy nem minden esetben kívánatos a lehető legszélesebb körü bevonás (Pataki 2007), hiszen például egy folyó szabályozását érintő kérdésben a tágabb közösség - értsd: egy országrész - érdeke felülemelkedhet a folyó mellett élő halászok 'lokális' érdekein, márpedig egy-egy országrészen élő embertömegeket érintő kérdésekben nem szerencsés eszköz a közösségi tervezés. Szintén megjegyzendő, és állításunkkal („széles társadalmi részvételre való lehetőség") látszólag ellentétes, hogy a tervezés körüli dialógus informatikai eszközökre történő átterelése kizárhat bizonyos társadalmi csoportokat, például az alacsony jövedelmű nyugdíjasokat vagy az iskolázatlan romákat. Ezért a webes platformon történő tervezés többnyire kiegészíti a hagyományos módszereket, nem helyettesíti azokat.

- Átláthatóság és tudásépítés. Az online felületeken történő társadalmi vita és tervezés rendszerezett, átlátható és archiválható. Sokkal egyszerübben visszakövethető a későbbiekben a tervezési folyamat, ami a 
programozás működését teszi érthetőbbé egyrészről az állampolgár, más tekintetben a tervezők részére. Egyfelől tehát a demokrácia erősödik azáltal, hogy érthetőbbé válik a közösséget befolyásoló tervek születése, bizonyos mértékig nyomon követhető az egyes résztvevők hozzájárulása, másfelől szinte automatikusan kerül kategorizált és kereshető módon archiválásra az a tapasztalat és tudásanyag, ami a résztvevőktől és a tervezőktől származik.

- Gyorsaság és gazdaságosság. A magas idő- és költségvonzat a számos fordulóból álló, facilitátor által vezetett fókuszcsoportos és nyilvános vitákból álló közösségi tervezési folyamat egyik legnagyobb hátránya. Ezzel szemben a többnyire „kulcsrakészen” használható, web 2.0 alapú tervezési platformok használatához nem kell termeket bérelni és füteni, az adatok összegzése sok esetben automatikus, és a facilitátor tevékenysége nagymértékben automatizálható. A fókuszcsoportos brainstorming és vizuális eszközök segítségével történő tervezés során sok idő megy el arra, hogy a több résztvevő vagy a facilitátor a táblára cetliket ragasztgat, térképeken rajzol/jelöl stb. Az ilyen jellegü, csoportos, vizuális segédeszközökkel történő ötletelés és gondolkodás a webes felületen nagyságrendekkel gyorsabb. Kétségtelen, hogy általános a szkepticizmus az olyan megoldások irányában, amelyek a személyes részvételt virtuális felülettel helyettesítik. Megválaszolandó kérdés, hogy a személyes részvételkor kialakuló csoportdinamika és egyéb, megfoghatatlan többletek milyen mértékben jönnek létre akkor, hogyha nem személyes, hanem virtuális a kontaktus a résztvevők között.

A participatív tervezés elméletét alkalmazása során lehet torzítani, manipulatívan felhasználni. Három lehetséges tévutat különböztethetünk meg:

1. Kooptálás: a participatív tervezés folyamán gyakran alkalmazott módszer, hogy a helyi érdekszervezetek csupán „szóvivőiken” vagy képviselőiken keresztül érvényesíthetik érdeküket a tervezőkel történő egyeztetésekben. E gyakorlat fö előnye, hogy jelentősen felgyorsítja és egyszerüsíti a folyamatot, mert kevesebb a résztvevő. A tapasztalat azt mutatja, hogy ilyenkor a csoportok képviselői hajlamosak békülékenyen közelíteni az álláspontjukat, tompítva a mögöttük álló csoportok kritikájának-álláspontjának az élét. A webkettes eszközök segítségével történő kommunikatív tervezés elkerülhetővé teszi, hogy a „tömeget”, magukat az érintetteket szóvivők áttételén keresztül nélkülözzék - a folyamat gyorsaságának és gördülékenységének jelentős mértékű feláldozása nélkül.

2. Manipuláció: az egyik leggyakrabban hangoztatott kritika a kollaboratív tervezéssel szemben, hogy az érintettek nem egyenlő képességekkel szállnak vitába. Így fordult elő az Egyesült Államokban többször, hogy a lakosság a felkészült ingatlanbefektetési társaságokkal szemben - stratégia hiányában - olyan konszenzusba ment bele, ami később a megállapodás mentén helyi ingatlanok áron aluli felvásárlásához, 
egyes területek kisajátításához vezetett (Ghose 2005). A tervezés folyamán megfogalmazott kérdéseket, illetve a beérkezett vélemények szelektálását, felhasználását a tervezők és a politikusok végzik. Adott a lehetőség arra, hogy ez valamilyen értékválasztás, prekoncepció alapján történjen. Az ilyen manipulatív törekvéseket a webes technológia sem tudja kiküszöbölni.

3. (Fölösleges) konszenzus: A kommunikatív tervezők gyakran - hibásan arra törekszenek, hogy esetleg „összebékítéssel” konszenzus alakuljon ki az érintettek között. Szituációtól és céloktól függően nem mindig kívánatos az egyetértés, hiszen gyakran „a konfrontáció, az érdekütköztetés visz előre, ez a változások mozgatórugója, és akár a kölcsönös megértésen nyugvó megegyezés is konzerválhatja a status quot, amelynek jövőbeli megítélése bizonytalan" (Faragó 2005). Itt meg kell említeni, hogy a konszenzus létrejöttét megelőzheti a konfrontatív vita. A webes kollaboratív tervezés mint eszköz ezen a félrealkalmazási hibán sem tud segíteni.

Jeffrey (2003) felhívja a figyelmet arra, hogy empirikus kísérletek, mérések nem állnak rendelkezésre annak bizonyítására, hogy a közösségi tervezés révén születő projektek egyértelműen jobban szolgálják az érintettek érdekeit, mint a nélkülük született tervek mentén megvalósulók. Ezzel együtt, valamint a fent említett Ghose- és Faragó-féle kritikákat/veszélyeket tudomásul véve úgy értékelem, hogy támogatandó a (webkettes) kollaboratív tervezés gyakorlata, hiszen azzal a fontos mellékhatással jár, hogy az érintettek sokkal inkább „magukénak érzik” azt a teret, közeget, aminek a formálásában érdemi módon részt vehetnek. Ez a fajta elköteleződés pedig közvetlenül eredményezi a nagyobb tiszteletet és szeretetet-kötődést a hely iránt, amely érzelmi többlet hozzájárul a magasabb életminőséghez (Rechnitzer 2004). Emellett létezik egy vitathatatlan és jóval kézzelfoghatóbb haszna a webkettes eszközök bevonásának a participatív tervezésbe; ez a gyors és költséghatékony helyi adat- és információgyüjtés.

\section{Webkettes kollaboratív tervezés a gyakorlatban}

A participatív közösségi tervezésbe bevitt információtechnológiai eszközök - így a webkettes alkalmazások - a kommunikációt, az adatgyüjtést és az elemzést segítik. Sem a részvételi tervezés folyamatát, sem a résztvevők szerepeit nem érinti alapvetően a technológia, de kiegészíti és esetenként helyettesítheti a hagyományos, személyes megjelenést igénylő, csoportmunkát involváló közösségi tervezést. Egyrészt követi a hagyományos eljárásokat virtuális közegben, másrészt kiegészíti őket. Ezek a platformok Sain (2008) rendszerében mind a hat szinthez nyújthatnak támogatást, ahogy az alább bemutatandó modellből kiderül. 
Példánk a Peng (2001, 128-132.) által publikált közlekedésfejlesztési projekt támogatására kialakított webes felület ismertetése; e rendszer fejlesztése számos amerikai egyetemen összehangolt kutatás keretében folyik Participatory Geographic Information System for Transportation Decision-Making néven (participatív geoinformatikai rendszer a közlekedéstervezési döntések támogatására). E kutatások célja olyan döntéstámogatási rendszer megalkotása, ami webalapú, nagymértékben hasznosítja a geoinformatika eszköztárát, és kifejezetten nagy csoportok közös munkáját szolgálja. Támogatja mind a valós idejü, mind a virtuális közös munkát (a virtualitás itt az időben nem egyszerre történő webes interakciót jelenti), és egy öt lépésből álló lineáris folyamatra épül fel, amelyben a résztvevők egy nagy csoportban „mozognak”. Az öt lépés:

1. A problémák megfogalmazása (describe concerns): Ebben a fázisban a résztvevők az általuk érzékelt közlekedési problémákat viszik fel szavak vagy rövid tőmondatok formájában egy mindenki által hozzáférhető oldalra a webes rendszeren belül. A program automatikusan kiemeli a leggyakrabban előforduló szavakat - ezek a kulcsszavak. Rájuk kattintva a felhasználók láthatják a kapcsolódó bejegyzéseket, kommentárokat. (A résztvevők ugyanis megjegyzéseket is füzhetnek a bejegyzésekhez, és fórumszerüen vitázhatnak egyes problémákról.) A folyamat végén a moderátor, aki a programot müködtető ügynökség egy vagy több munkatársa, szintézist készít, amit szintén meg lehet vitatni fórumszerüen a programban. A szintézis megfelelő számú újrafogalmazása után hivatalos, a problémákat összegző dokumentum készül.

2. Kritériumok meghatározása (determine criteria): Ebben a lépésben a tervezést vezetö ügynökség munkatársai megfogalmaznak néhány olyan kritériumot, mérőszámot, amelyek által behatárolhatóvá, mérhetővé válnak a résztvevők által felvetett problémák. Ezek rendszerint mérőszámok és minőségek, amelyeket a későbbi fázisokban is használni fognak. Példaként a szerzők a következőket említik meg (3. táblázat).

A résztvevők a szakértői listát egy fórumon megvitatják, majd amikor egyességre jutnak a kritériumok felől, önállóan súlyozzák azokat vélt

\section{3. táblázat: A problémák és a kritériumok összekapcsolása}

\begin{tabular}{ll}
\hline \multicolumn{1}{c}{ Probléma } & \multicolumn{1}{c}{ Kritérium } \\
\hline Biztonság & $\begin{array}{l}\text { A személysérüléses és halálos balesetek száma, illetve vagyoni } \\
\text { károk (mennyiségben és pénzben kifejezett kár) }\end{array}$ \\
Környezeti hatások & $\begin{array}{l}\text { Nitrogénvegyületek és széndioxid kibocsátása } \\
\text { (mennyiségben és pénzben kifejezett kár) }\end{array}$ \\
Időmegtakarítás & $\begin{array}{l}\text { Az átlagos utazási idő csökkenése a projekt implementálása } \\
\text { esetén (mennyiségben és pénzben kifejezett haszon) }\end{array}$ \\
\hline
\end{tabular}

Forrás: Peng (2001). 
fontosságuk szerint. Végül a moderátorok (az ügynökség részéről) klaszteranalízist használva klaszterekbe és szettekbe csoportosítják a kritériumokat.

3. A projektek áttekintése (review projects): A tervezéssel foglalkozó szakemberek egy listát állítanak össze azokból a projektekből, amelyek megoldást jelenthetnek a résztvevők által felsorolt problémákra. A projekteket a szakértők rangsorolják-értékelik. A résztvevők véleménymegnyilvánulása egy GIS-platformon keresztül történik, ahol áttekinthetik a tervezett projekteket (jelen esetben közlekedési infrastruktúra-fejlesztést) a földrajzi elhelyezkedés szempontjából. Ugyanezen a platformon egy chatszerű alkalmazás (valós idejű, internetes „csevegés”) segítségével valós időben, illetve virtuálisan megoszthatják gondolataikat, elképzeléseiket a fejlesztésről.

A szoftver kezelőfelületén a felhasználó által zoomolható térkép a bal felső sarokban helyezkedik el. A képernyő jobb oldalán különböző területi kritériumok alapján szürhetők a térképen megjelenített projektek, míg középen a felhasználó által kiválasztott projektről szóló információk találhatók. A bal alsó sarokban chatablak található, a jobb alsó sarokban kommentár füzhető a kiválasztott projekthez, a két panel között pedig szavazat adható le a projekt értékelésére.

A projektek értékelésében kívánatos a konszenzus a tervező szakemberek és a résztvevők között. Amíg ki nem alakul az egyetértés, addig a chatben, illetve a nem valós idejü, virtuális hirdetőtáblán folyik a diskurzus a projektek értékeléséről és a rangsorolásról.

4. A forgatókönyvek értékelése (evaluate scenarios): A forgatókönyv jelen esetben a javasolt projektek adott csoportját jelenti. A forgatókönyvek száma megegyezik a két lépéssel korábban meghatározott kritériumszettek számával, mivel mindegyik forgatókönyv a külön kritériumklaszterek által összegzett problémákra adandó megoldás. Ebben a fázisban is a tervezők állnak elő a szcenáriókkal, amit aztán a résztvevők egymás közt megvitatnak az online felületen. Rendszerint ebben a lépésben is addig folyik az egyezkedés, amíg a többség részéről az egyetértés ki nem alakul.

5. A közös jelentés elkészitése (create group report): A közös jelentés első változatát is a moderátor készíti el. A következő elemeket tartalmazza a jelentés:

- Melyik forgatókönyv élvezi a legmagasabb támogatottságot, illetve a résztvevők mekkora hányada támogatja az adott forgatókönyvet?

- Melyik forgatókönyvet támogatja a kisebbség, illetve milyen mértékủ a támogatottsága?

- Milyen kétségei, aggodalmai vannak a résztvevőnnek?

- Melyik kritériumot választották a résztvevők a projekt és a szcenáriók értékelésére?

- Milyen súllyal „szavaztak” a résztvevők ezekre a kritériumokra? 
A résztvevők a webes felületen kommentárokat írhatnak és módosításokat javasolhatnak a jelentéshez. A vita addig folyik, amíg létre nem jön a jelentés többségi támogatottsága. Hogyha a résztvevők többsége több kör után sem jut egyezségre a dokumentum elfogadásáról, az ügynökség „kiveszi a kezükből”, és maga fejezi be. Ezt a mozzanatot a végső jelentésnek tartalmaznia kell.

A fenti példa kifejezetten infrastruktúra-fejlesztési projektek közösségi részvételére ösztönöz, de a technikai eszköz és a módszertan elég általános ahhoz, hogy más, az állami szektorban folyó tervezési projektet is támogassanak vele.

Hangsúlyozni kell, hogy a fenti példában bemutatott webkettes technológiával történő közösségi tervezés nem képez új metodológiát - csupán egy eszköz, ami

- gyorsabb és gazdaságosabb;

- szélesebb részvételt tesz lehetővé az érintettek számára és

- átláthatóbb

a hagyományos, személyes jelenlétet igénylő participatív tervezésnél. Webkettes tervezési eszközök a tervezés minden fázisában alkalmazhatók a vízióalkotástól egészen az értékelésig. Az értékelés során az elektronikus formátumban rögzített implicit tapasztalatok és az új, objektív tudás feldolgozása részben számítógépes, részben „manuális” adatelemzéssel történik, akárcsak a web 2.0-s platformokat nélkülöző kommunikatív tervezés során. A webkettes technológiák óriási előnye, hogy olcsón és gyorsan lehet sok résztvevőt bevonni, és így hatalmas adatmennyiséghez hozzájutni. Az, hogy egy adott közösségi tervezési projektbe érdemes-e kiegészítésként - facilitálás végett vagy akár a személyes konzultációt helyettesítő médiumként - bevonni e technológiát, a közönség adaptációs hajlandóságától függ. Attól, hogy a résztvevők körében milyen mértékủ a számítógépes műveltség. Időskorú és mélyszegénységben élő közösségekben várhatóan alacsony az eszközök adaptációja.

A technológia alkalmazhatóságának eldöntése végett tehát meg kell határozni, hogy hány résztvevőre számítunk, és mekkora lesz az arányuk a közösség egészéhez képest? Ha a résztvevőknek csak egy kis hányada vesz részt a webes interaktivitásban, és a személyes részvételen alapuló eseményeket mindenképp meg kell rendezni, akkor elképzelhető, hogy nem költséghatékony a külön ráfordítás; nem éri meg, hogy mindössze 5-10\%-kal több választ/adatot kapjunk a web révén. Az, hogy mekkora többletráfordítást „ér meg" a webkettes alternatíva, projektfüggő. Egy tervezési projekt esetében az alkalmazhatóság kérdésének eldöntése a fentinél jóval körültekintőbb vizsgálatot igényel, amelynek részletes ismertetése jelen cikk keretein kívül esik.

Fent említettem, hogy a csoportos, személyes jelenlétet igénylő fórumokon fennáll annak a lehetősége, hogy a bátrabb és jobb kommunikációs képességgel rendelkező résztvevők véleménye túlreprezentált lesz. Ennek veszélye a PPGIS-szerű webkettes rendszereknél csökken, hiszen a számítógép képernyője és esetleg egy anonim név mögé bújva bátrabban nyilvánul meg az ember, mint egy nagy teremben rendezett fórumon. Nem csökken azonban 
annak a jelenségnek a torzító hatása, amit a többség véleményének ismerete utáni „tömegkövetés” idéz elő; magyarán az ember véleménye hajlamos konvergálni a többség által reprezentált állásponthoz, amennyiben az ismert. Ez a hatás azonban kiküszöbölhető lenne a PPGIS-ben azáltal, hogy a résztvevők elől rejtve lenne a többiek véleménye az értékelési (3-as) stádium kezdeti szakaszában.

A webkettes közösségi tervezés procedúrájának van egy mozzanata, ami az offline tervezésben nem, vagy alig duplikálható. Ez a dokumentumok közös elkészítése, kommentálása (PPGIS 5. lépés). Van ugyan lehetőség arra, hogy a nyilvánosság bármilyen webkettes platform nélkül is e-mailben vagy nyílt fórumon kommentáljon egy dokumentumtervezetet, mint ahogy ez a magyar tervezési gyakorlatban is évek óta ismert. Ennek fejlettebb változata az élöben történő kollaboratív dokumentumszerkesztés, amit egy webkettes technológia tesz lehetővé azáltal, hogy a dokumentum egy szerveren van, amelyhez minden érintett hozzáfér, és képes valós időben szerkeszteni, kommentálni webes böngészőjén keresztül. Természetesen a kollaboratív dokumentumszerkesztés csak bizonyos résztvevőszám alatt működhet, így az említett PPGIS-példában úgy valósulhatna meg, hogy az érintettek kisebb csoportokat alakítanak, részekre osztják az elkészítendő vagy átírandó dokumentumot, és minden csoport csak a rá kiszabott részt készíti el.

Végül meg kell említeni a PPGIS kapcsán is, hogy a webes platform nemcsak sok információ gyors begyüjtésére alkalmas, de másfajta, tacit tudások ${ }^{3}$ megragadására, dokumentálására is. Az offline közösségi tervezésben a lakossági gyűlések során az elmondottak mellett felszínre kerülhetnek, érzékelhetővé válhatnak bizonyos érzelmek, tapasztalatok, hangulatok, amelyeket egy képzett, empatikus tervező meg tud ragadni, ezeket verbalizálni képes későbbi jelentéseiben mint információt/tanulságot. Ha egy tervezési projekt kapcsán a lakossági gyülések helyett vagy azok mellett blogokon vagy online fórumokon is folyik a diskurzus a résztvevők között, akkor több lehetőség nyílik az ilyen jellegű szubjektív, tacit információk megnyilvánulására és befogadására. Jól látható, hogy az ehhez hasonló webkettes technológiák - az arra alkalmas projekt és résztvevői kör esetén - a Sain-féle közösségbevonási skálán a participáció legfelsőbb szintjein is képesek akár teljes mértékben helyettesíteni a személyes találkozókat.

A közösségi tervezéssel foglalkozó szakirodalom jelentős része a demokrácia netovábbjának tekinti a participatív tervezést. Kevésbé tűnik naivnak Faragó (2005) álláspontja, aki felhívja a figyelmet arra, hogy a közösség bevonásával is gyakori a részérdekek ütköztetése és valamelyik felülkerekedése, így egyáltalán nem garantálható a közösség hosszú távú érdekeinek győzelme. Lyotardra hivatkozva felhívja a figyelmet arra, hogy „konszenzus 'mesterséges' létrehozásához elég olyan módszereket alkalmazni, amelyek elérik az egyéneknél, hogy azt akarják, amit a rendszer teljesítőképessége megkíván. Ez esetben viszont jóformán alig távolodtunk el [a hagyományos] terve- 
zési alaptípustól. Finomabb eljárásokkal ugyanazt az eredményt érjük el, mint a nyers hatalomérvényesítéssel, a tervlebontással" (Faragó 2005, 153.). Ennek ellenére megjegyzi, hogy kívánatos minél több érintett bevonása a tervezésbe. Ez a vélemény gyakorlatilag egybeesik a néhány bekezdéssel feljebb említett Ghose-féle manipulációval. Akadnak ellenpéldák is: néhány hazai eset bizonyítja, hogy például egy tervezési szituációban az ilyen jellegü manipulálás ellen megfelelő védelmet nyújthat a kellően aktív és erős helyi civil bázis. A Tubesre tervezett lokátor vagy a Páty határába tervezett golf-falu megépülése elleni eredményes civil fellépés arra utal, hogy a befektetői vagy a politikai nyomás és manipuláció ellensúlyozható civil aktivitással és a szélesebb nyilvánosság bevonásával. $\mathrm{E}$ két eset egyébként nem minősül közösségi tervezésnek, de jól mutatja, hogy a manipulációnak akár közösségi tervezési szituációban is ellenszere lehet a nyilvánosság és a civil aktivitás (de természetesen nem küszöbölheti ki). A civilek és a nyilvánosság megszólítására pedig kiváló médium a web 2.0.

A hazai gyakorlatban sajnos hiába keresünk eseteket a webkettő alapú közösségi tervezésre. A hagyományos offline participatív tervezés terén sem járunk élen, de vannak biztató példák; a Studio Metropolitana több ízben asszisztált közterek átalakításának megtervezésekor a helyi lakók bevonásában, illetve a Közösségfejlesztők Egyesülete magyar falvakban (például Tardoson) is végzett tervezési projekteket. Webkettes eszközök bevonásáról azonban nincs tapasztalat, legfeljebb elkészült dokumentumok online vagy emailes kommentálásáról.

\section{Összegzés}

A participációt - a tervezés érintettjeinek bevonását saját sorsuk alakításába egyre gyakrabban alkalmazzák a közösségi tervezésben. Szemléletmódja amely szorgalmazza a kommunikációt, az alulról építkező tudás integrálását, ötletek és víziók alkotásának demokratizálását - egybecseng az internetes kommunikációban és tartalomszolgáltatásban megjelenő új paradigma célkitűzéseivel. A jelenséget átfogóan web 2.0-nak nevezik. A webkettő egyrészt tartalomszolgáltatás, tudásmegosztás, másrészt webes platform, keretrendszer. A közösségi részvételen alapuló tervezés és a web 2.0 egymásra találásával olyan webalapú célalkalmazások születnek, amelyek a hagyományos személyes jelenlétet igénylő részvételi tervezést nagymértékben gyorsítják, olajozottabbá és olcsóbbá teszik, erősítik a demokratikus részvétel lehetőségét. E második generációs webes szolgáltatások bevonása hozzájárul a helyi tudások és kompetenciák felértékelődéséhez, valamint lehetővé teszi nagy mennyiségű információ és adat begyüjtését gyorsan és alacsony költségen. 
További lehetőség a web 2.0 és a közszféra kapcsán a government 2.0 vizsgálata, illetve a webkettő térhasználatra gyakorolt, itt bemutatott hatásának kutatása.

\section{Jegyzetek}

1 Hub-and-spoke megoldások: alapjuk egy központi integrációs platform (hub), amely kisebb egységekkel (spokes), például egy vállalat telephelyeivel vagy üzleti partnereivel van összeköttetésben. A vezérlés a vállalat központjából történik. A résztvevők közötti adatátvitel az intraneten vagy az interneten zajlik (www.seeburger.hu).

2 Facilitátor: megkönnyítő, segítő.

3 Tacit tudás: kimondatlan, az emberek fejében rejtőző - szemben az explicit tudással.

\section{Irodalom}

Arnstein, S. R. (1969): A ladder of citizen participation. Journal of the American Institute of Planners, 4., 216-224.

Berényi K. (2008): ...ez valami más! http://onlinemarketing.blog.hu/2008/02/15/ez_valami_mas Letöltve: 2009. február 9.

Faragó L. (2005): A jövőalkotás társadalomtechnikája. Dialóg Campus, Pécs

Ghose, R. (2005): The complexities of citizen participation through collaborative governance. Space and Polity, 1., 61-75.

Graham, P. (2005): Web 2.0 - http://www.paulgraham.com/web20.html Letöltve: 2009. szeptember 21.

Gunder, M. (2003): Passionate planning for the others' desire: an agonistic response to the dark side of planning. Progress in Planning, 3., 235-319.

Jeffrey, P. (2003): Participative planning and ICT tools; identifying and evaluating the benefits http://vr.arch.uth.gr/pict-dvd/websites/econference.pict.hu/papers/11/Jeffrey\%20\%20Participative\%20planning\%20and\%20ICT\%20tools.pdf Letöltve: 2009. december 4.

Kaner, S., Lind, L., Toldi, C., Fisk S., Berger D. (1996): The Facilitator's Guide to Participatory DecisionMaking. New Society Publishers, Gabriola Island, B. C., Canada

Karamagi, E. A., Nakirya, M. (2007): Tools for enhancing knowledge-sharing in agriculture: improving rural livelihoods in Uganda http://www.iied.org/pubs/pdfs/14563IIED.pdf\#page=61 Letöltve 2009. november 12.

Mass Mingling http://www.trendwatching.com/briefing/\#massmingling Letöltve: 2009. november 23.

McPherson, M., Smith-Lovin, L., Brashears, M. (2006): Social Isolation in America: Changes in Core Discussion Networks over Two Decades. American Sociological Review, 3., 353-375.

O'Reilly, T. (2005): What is Web 2.0 http://oreilly.com/web2/archive/what-is-web-20.html Letöltve: 2009 . november 24 .

O'Reilly, T. (2006): Web 2.0 compact definition: trying again http://radar.oreilly.com/archives/2006/12/web-20-compact-definition-tryi.html Letöltve: 2009. január 28.

Pataki Gy. (2007): Bölcs „laikusok” - Társadalmi részvételi technikák a demokrácia szolgálatában. Civil Szemle, 3-4., 144-156

Peng, Z-R. (2001): Internet GIS for public participation. Environment and Planning B, Planning and Design, 6., 889-905.

Rechnitzer, J. (2004): A tudás és technológiatranszfer lehetőségeinek jobb kihasználása a regionális különbségek csökkentésére. Nyugat-Magyarországi Tudományos Intézet Közleményei, 162. 
Sain, M. (2008): Helyi részvételen alapuló közösségi tervezés c. előadás diái a Társadalmi-közösségi tervezés települési és kistérségi szinteken konferenciáról, 2008. február 5-6, Budapest

Sarkissian, W. (2002): New Directions - Community Participation in Practice Murdoch, Australia

Terdiman, D. (2005): Study: Wikipedia as Accurate as Britannica http://news.cnet.com/2100-1038_35997332.html Letöltve: 2010. február 22.

Toffler, A. (2006): Revolutionary Wealth. Random House, New York

Vickery, G., Wunsch-Vincent, S. (2006): Participative Web and User-Created Content: Web 2.0, Wikis and Social Networking in Science\&Information Technology, 1-128. Letöltve 2009. december 21. http://213.253.134.43/oecd/pdfs/browseit/9307031E.PDF

Wates, N. (1996): Action Planning. Prince of Wales Institute of Architecture, Cardiff

Web 2.0 szócikk: http://en.wikipedia.org/wiki/Web_2.0 Letöltve: 2009. december 12.

Wikitravel: Milestones http://wikitravel.org/en/Wikitravel:Milestones Letöltve 2010. január 31. 